\title{
Article
}

\section{"Carbon literacy practices": textual footprints between school and home in children's construction of knowledge about climate change}

\author{
Satchwell, Candice
}

Available at https://clok.uclan.ac.uk/7242/

Satchwell, Candice orcid iconORCID: 0000-0001-8111-818X (2013) "Carbon literacy practices": textual footprints between school and home in children's construction of knowledge about climate change. Local Environment, 18 (3). pp. 289-304. ISSN 13549839

It is advisable to refer to the publisher's version if you intend to cite from the work. http://dx.doi.org/10.1080/13549839.2012.688735

For more information about UCLan's research in this area go to http://www.uclan.ac.uk/researchgroups/ and search for <name of research Group>.

For information about Research generally at UCLan please go to http://www.uclan.ac.uk/research/

All outputs in CLoK are protected by Intellectual Property Rights law, including Copyright law. Copyright, IPR and Moral Rights for the works on this site are retained by the individual authors and/or other copyright owners. Terms and conditions for use of this material are defined in the policies page. 


\title{
"Carbon literacy practices": textual footprints between school and home in children's construction of knowledge about climate change
}

\author{
Candice Satchwell
}

\begin{abstract}
This paper examines the notion of "carbon literacy practices" through reporting on a small research project aimed at understanding how children make sense of climate change, and their subsequent related practices at school, at home, and in the community. Drawing on a background in New Literacy Studies (e.g. Barton et al 2000; Satchwell \& Ivanic 2009 and 2010), the paper explores the relationships among children's understanding of climate change, their literacy practices in relation to climate change, and their environmental social practices. Data is included from a project involving children and their families from three primary schools - with and without "eco-school" status, which asked: What and how do children learn about climate change at school? What and how do they learn at home and outside of school? How do these kinds of learning relate to each other, and how is what they learn put into practice? Put simply, how might children become "carbon literate" citizens? This article will report on the methodological challenges of the project and the use of some innovative methods to address these using mobile technologies.

In addition, the paper interrogates the notion of children as agents of change. The concept of children influencing the behaviour of others sounds convincing, but is based on a straightforward model, described by Shove (2010) as the ABC model - which is considered an effective strategy in health care (stopping parents smoking) and in marketing (persuading parents to buy certain products), but is not necessarily transferable to other contexts. Further, it is clear from work in literacy studies and education (Ivanic et al 2009; Gee 2003; Reinking et al 1998; Tuomi-Grohn and Engestrom 2003) that the transfer of linguistic and semiotic signs is by no means equivalent to the transfer of knowledge, values or functions. In other words, a school lesson or a computer game about climate change and its effects does not automatically mean that a child will turn the lights off at home. The paper considers these issues with reference to qualitative data collected from observations, conversations on "Twitter", focus groups, and individual interviews.
\end{abstract}

Key words: literacy practices, education, carbon literacy, children

\section{Introduction}

This article expands and redefines the notion of "carbon literacy", by exploring the relationships among children's understanding of climate change, their literacy practices in relation to climate change, and their environmental social practices. Drawing on a background in New Literacy Studies (e.g. Barton et al 2000; Satchwell \& Ivanic 2010), I consider the role of texts about climate change in influencing children's understanding and practices. I include data from a project involving children and their families from 
three primary schools - with and without "eco-school" status ${ }^{1}$, which asked: What and how do children learn about climate change at school? What and how do they learn at home and outside of school? How do these kinds of learning relate to each other, and how is what they learn put into practice? Put simply, how might children become "carbon literate" citizens?

In the following, I argue for the value of using "carbon literacy practices" as a concept, drawing on ideas developed from the study of "literacy practices". Some terms that I use in this article are summarized below.

\begin{tabular}{|l|l|}
\hline Term & Explanation \\
\hline “carbon literacy" & $\begin{array}{l}\text { as used to refer to deeper understanding/ } \\
\text { application of knowledge about the carbon } \\
\text { cycle }\end{array}$ \\
\hline "literacy practices" & $\begin{array}{l}\text { social practices around texts involving reading } \\
\text { and/or writing }\end{array}$ \\
\hline “carbon literacy" practices & $\begin{array}{l}\text { social practices which are related to } \\
\text { knowledge about the carbon cycle }\end{array}$ \\
\hline "carbon literacy" literacy practices & $\begin{array}{l}\text { social practices using texts which are related to } \\
\text { knowledge about the carbon cycle }\end{array}$ \\
\hline
\end{tabular}

\section{Carbon literacy practices}

The coinage here of the term "carbon literacy practices", entails both the notions of "carbon literacy" and "literacy practices". Both require some explanation. "Carbon literacy" is a term becoming widely used in everyday language. Like many uses of the word "literacy" when combined with another term, the implication is of a deeper understanding of an issue and application of knowledge - as in emotional literacy, physical literacy, and environmental literacy. Carbon Sense, a company which aims to help businesses find solutions to climate change issues, makes a direct link between "lack of knowledge" and "carbon illiteracy": "most people, while aware of the climate change issue, do not fully understand what the concept means or grasp the implications: they are 'carbon illiterate'." 2 The UK government has recently (October 2011) produced a carbon literacy e-learning resource "to develop awareness and understanding of the terminology and principles associated with the greenhouse effect and climate change". ${ }^{3}$ Low Carbon Trust ${ }^{4}$ explains:

"The first step to reducing your own personal carbon emissions is to realise how much carbon dioxide your life and activities may be causing. Every time we use a car, every time we use the heating in our homes and every time we eat processed food from a supermarket we are using fossil fuel and in turn releasing carbon dioxide";

1 "Eco-Schools" is an international programme run by the Foundation for Environmental

Education; further details below.

\footnotetext{
${ }^{2}$ http://carbonsense.com/index.htm

${ }^{3}$ http://sd.defra.gov.uk/2011/10/new-carbon-literacy-e-learning-resource/

${ }^{4}$ http://www.lowcarbon.co.uk/home/carbon-literacy
} 
while Cut Your Carbon ${ }^{5}$ describes itself as: "enabl[ing] pupils and teachers to become more carbon literate."

The use of the term "carbon literacy" in all these cases suggests more than, say, recycling bottles once a week. Rather, it indicates that in order to understand how to reduce the effects of climate change, an understanding of the carbon cycle is required. ${ }^{6}$ These quotations all also assume a link between knowledge and action - a link that I question in this paper.

"Literacy practices" is a term from New Literacy Studies (Street 1984; Baynham 1995; Barton 2007), which describes reading and/or writing as social practices involving texts, and presents an alternative to the view that literacy is simply a set of skills to be learnt by individuals and transferred from one context to another. Barton, Hamilton \& Ivanic (2000) summarise:
"Literacy is best understood as a set of social practices; these can be inferred from events which are mediated by written texts.
There are different literacies associated with different domains of life.
Literacy practices are patterned by social institutions and power relationships, and some literacies are more dominant, visible and influential than others.
Literacy practices are purposeful and embedded in broader social goals and cultural practices.
Literacy is historically situated.
Literacy practices change and new ones are frequently acquired through processes of informal learning and sense making." (p. 8)

These points indicate the variety of factors to be considered when thinking about literacy, and suggest the importance of context - including what, where, when, who with, who for, why and how, for any instance of reading or writing. There is by no means a clear lineage from knowledge to action: using reading and writing in everyday life is not simply knowing how to decode and encode language.

If we use Barton et al's list as a starting point for considering "carbon literacy" by inserting "carbon" in front of "literacy" - we can see that this concept becomes equally sophisticated and complex. While the focus of literacy studies is the social practices of reading and writing texts - of all kinds, including electronic and sometimes spoken or visually mediated texts, the focus of carbon literacy is the environment, and social practices involved in conserving carbon.

So, while literacies are part of social practices that are observable in literacy "events" or "moments" and are patterned by social institutions and power relationships, carbon literacy is observable in carbon literacy events, which constitute socially patterned carbon literacy practices. In the study of literacy, this approach encourages us to look beyond texts themselves to what people do with literacy, with whom, where and how. For example, by analysing the respective literacy practices of a student researching material for college coursework and that same young person searching for information about dogs suitable for the family, we can explain why a student might find one exercise "easier" than the other. (See below for further examination.) With reference to carbon literacy, the approach enables us to look in detail at the practice of, for example, recycling paper, in all its components, including social expectations,

\footnotetext{
${ }^{5}$ http://www.cut-your-carbon.co.uk/

${ }^{6}$ UK Department for Transport - Public attitudes towards climate change and the impact of transport,

February 2009
} 
institutional facilities, and so on, and how these aspects might interact with individual attitudes, values and capabilities. This in turn enables us to look at how that might be quite different from recycling plastic, or glass; or how recycling at work might involve different elements from recycling at home.

I contend that a literacy studies approach to "carbon literacy" is helpful in that it views literacy not as a set of discrete skills to be acquired by individuals, but as a set of social practices. Shove (2010) argues that if we are to tackle the multi-faceted challenges posed by global climate change we need to move away from an individual behavioural model of change towards serious engagement with wider understanding of social change. The concept of "carbon literacy practices" resonates with this approach in that it embodies a view of environmental practices being socially embedded.

Interestingly, in a discussion of "environmental literacy", Corbett (2006) describes a hierarchy of knowledge, rather like the ways in which literacy is traditionally described as a set of competences to be achieved, which can then be "tested" at various levels. In relation to literacy this would be described as a deficit model, which advocates of new literacy studies would find unhelpful and misleading in terms of how literacy works in everyday life. Corbett states:

"First, it's important to distinguish between types of knowledge. ... 'awareness' ... 'personal conduct knowledge' ... A significantly higher level of knowledge is 'environmental literacy,' which is equated with more in-depth information and an understanding of underlying principles, consequences, and applications. As you might guess, very few Americans can be considered environmentally literate. Roper polling estimates just 2 percent of adults qualify, though the percentage increases with education level." (Corbett 2006)

Nevertheless, Corbett does acknowledge that these levels of knowledge do not necessarily equate to different behaviours:
"Although it may be logical to assume that knowledge affects attitude, and attitude affects behaviour, researchers have concluded that such a knowledge-attitude- behaviour model is too linear and simplistic. These three factors may be associated in some form but don't necessarily 'cause' one another. In most cases, the relationship between knowledge, attitude, and behaviour tends to be positive but not very strong." (Corbett, 2006, p.67)

Without approaching environmental literacy in terms of social practices, an individualistic model does not explain how someone could be environmentally literate but still throw their rubbish on the floor. This might be described as the "value-action gap" (Blake 1999), which Shove (2010) argues is "only mystifying if we suppose that values do (or should) translate into action" (p.1276). I am suggesting that understanding, knowledge and action do not necessarily follow from each other. Children can engage in making sense of climate change, and they can develop knowledge about it, which may lead to action - but this is not always the case. To understand why the relationship is not linear, it helps to look at the elements of practices and to think about transfer across domains. I suggest that the concept of carbon literacy practices is particularly useful for researchers and practitioners working with children and young people because it offers a method of identifying changes that might be required in order for them to engage more effectively in environmental practices, and therefore how environmental education might be modified to best address these "gaps". 


\section{Drawing from a literacy studies approach to examine carbon literacy practices}

Different literacy practices have different characteristics. One person can engage in any number of literacy practices in one day, or even at one time: for example, while I am writing this academic article, I am also checking emails, texting people, consulting other academic articles, searching websites, and opening post. Each of these is constituted differently, but I can switch easily from one to another and can easily adopt the requirements of each - from Standard English to informal text language; from screen to paper; and so on.

The different characteristics of literacy practices in different domains of social life can be mapped according to different aspects or elements which vary. As presented in Ivanic and Satchwell (2007 p.104), work has been carried out to identify these "building blocks of literacy", and can be used as an heuristic. The aspects identified are represented in Table 1 below:

Table 1: Aspects of a literacy practice

This means that a change in any of these elements can change the nature of the literacy practice. To take the example above, of a young person researching on the internet as (a) a student doing coursework; and (b) a daughter finding a suitable dog for the family, there will be significant differences in various aspects, even though the practice "appears" to be similar. It uses the same Artefact (computer), Text-type (web pages), Modes and Media; but is crucially different in the aspects of Audience (tutor/examining body vs family members), Purpose (to gain qualification vs to buy a dog), Place (college vs home), Identities (student vs daughter), and so on. Subtle differences in practices can make them more or less "in tune" with an individual's or group's preferred practices (see Mannion et al on "resonance", 2009). In order to understand the nature of children's environmental practices, I intend to bring the basis of this model to the case of children's carbon literacy practices in the different domains of their lives - at home, at school, and in their communities (Fig 2). By examining environmental practices in these different domains, we can attempt to understand their characteristics and see how a practice might - or might not - cross the boundary between school and home, or between home and community.

Figure 1: Domains for children's carbon literacy practices

\section{The study}

A small-scale study was carried out with the aid of funding from Lancaster University. The aim was to begin to investigate the links between children's interaction with texts about climate change - in school, at home, and in their communities, and their environmental practices - in school, at home, and in their communities. One school was chosen for being an "eco school": the Eco-Schools programme is run internationally by the Foundation for Environmental Education (FEE) as one of five 
environmental education programmes. ${ }^{7}$ Eco-Schools is managed in England by the environmental charity Keep Britain Tidy, which is the anti-litter campaign for England. The programme guides schools through a seven-step process to help them address a variety of environmental issues, ranging from litter and waste to healthy living and biodiversity, and schools work towards bronze, silver, and finally green awards. ${ }^{8}$ I worked with classes of approximately 28 children in Year 5 and Year 6 in an eco school, and in Year 6 in a non-eco school. I (a) conducted activities with the children in groups of five or six to ascertain their understanding of climate change, including trialling a number of websites aimed at children; (b) observed teaching sessions relating to climate change (including a climate change workshop carried out by a council-run initiative); (c) maintained a correspondence with children through writing letters; and (d) trialled a methodology with two separate groups of six children using mobile cameraphones and "Twitter", designed in collaboration with Infolab21 at Lancaster University. This was intended to engage children in ongoing conversations and to give them a space to represent some of their experiences and thoughts outside of school. I interviewed teachers and teaching assistants in the primary schools involved, three teachers in secondary schools, and a sample of six parents of the children involved.

A first step (a) was to find out something about children's "baseline" of understanding of environmental issues, or their initial carbon literacy status. First meetings with groups of children involved using laptops or PCs to trial web pages aimed at children on the subject of climate change. ${ }^{9}$ I also led discussions amongst the children about their understanding of the issue. Some of their comments are shown in Table 2 .

Table 2: Children's responses in climate change discussion

As I was interested in the lasting effects of input about the topic, I followed up the initial meetings with children with a letter (on paper) addressed and delivered individually to each child. These letters asked what they had remembered, whether they had talked to their parents, and whether any of their practices had changed. The resulting responses, perhaps predictably, made claims of having changed practices; having talked to their parents; and of course having remembered in detail what they had learnt. Examples are presented in Box 2. Such responses can be interpreted largely as a product of children's relationships with the institutional framework in which they were produced; for example a requirement that children show respect to "authority" figures; that they are polite and fulfil expectations; and that they demonstrate learning. The children's claims, e.g. "at the beginning we hardly knew anything; at the end we knew a lot more", along with "I have started to recycle" reflect the ABC model. However, disentangling the elements of these responses through further ethnographic research would be likely to suggest that the relationships between knowledge and action are not so straightforward.

Table 3: Children's written responses to letters

\footnotetext{
${ }^{7}$ The other four are Green Key, Young Reporters for the Environment, Blue Flag and Learning about Forests.

${ }^{8}$ See http://www.eco-schools.org/ for more details.

${ }^{9}$ e.g. http://www.globallink.org.uk/exhibitions/cc/game.html
} 


\section{Methodological considerations}

Having negotiated access to schools, methodologically it was relatively straightforward to research what children did at school in relation to climate change. It was possible to observe classes, interview teachers, talk to children - individually or in groups, and carry out activities with children. With further negotiation I could also gain access to parents and households of selected children, and interview household members about their environmental beliefs and activities, their relationship with their children's schooling, and even to monitor communications between children and parents about specific school events and activities.

Less easy to research, however, were the children's ongoing thought processes. How were they constructing knowledge about climate change? Where was their information coming from, and what sense were they making of it? In previous literacy studies projects, favoured research methods included giving participants cameras for a week and asking them to take photographs, which would then act as a stimulus for indepth interviews about literacy practices (e.g. Hodge 2000); using the "clock activity" (Satchwell 2005) to ascertain literacy practices over a 24-hour period; or other activities such as "icon-mapping" (Mannion \& Ivanic 2007) to locate literacy practices in different domains of life. For children, however, I thought we needed a method which would engage and enthuse them, and could be used "in the wild" outside of school. In order to address this problem, I consulted with the Infolab21 at Lancaster University, where cutting-edge research methods were being developed; for example, Pooley et al (2010) used GPS phones to track children on their journeys between home and school. A method which emerged for the purposes I had in mind was the use of the Twitter network. A group of five children were given a mobile phone each, which could be used only to contribute to an ongoing conversation on Twitter. As a researcher, I could access the conversation either via computer or via mobile phone. The network was closed, in that no-one would be given permission to "follow" the group. The children could choose to communicate only with me, or with one or more of the group members. They also had the facility to take photos and videos on their phones.

The instructions given to children with the phone were deliberately generalised. They included the following:

Sometimes I will ask you questions, so please answer.

Also, I want to know ANYTHING you want to tell me AT ANY TIME that relates to climate change in some way.

In particular:

When you get home from school each day, tell me if you have learnt anything to do with climate change at school.

Any time you see or hear anything about climate change at home, send me a text to tell me what it is.

If you DO or SEE anything that you think is to do with climate change, send a text.

(e.g. if you or someone in your family is putting out the recycling; if you see litter in the street; if you think the flowers are coming out earlier than usual, or the weather is unusual ...)

If you see a TV programme, find a website, or read anything of interest, let me know. If you have any thoughts at all, at any time, just send me a text - I will be interested! ALSO, you can use your phone to take photos relating to climate change. You can keep 
these on your phone, and I will collect them later.

Anything you tell me will be helpful to me and my project. So THANK YOU!

Candice.

It seemed important not to guide the children too firmly; but also to confine their communications to the topic at hand. The combination of instructions and method proved to be productive, but raised further methodological issues.

\section{Issues relating to the cameraphone and Twitter research method}

(1) I overestimated the children's texting dexterity. While I had assumed that children aged 10 or 11 would be adept at texting, this appeared not to be the case. For some children, this was the first time they had handled a mobile phone, and although we had some joint introductory sessions where I guided the children through how to use them, the texting itself proved problematic for some. This meant that parents or older siblings intervened, and it was not always easy to interpret the resulting data. While this collaborative use of technology was of interest in itself, particularly in examining the ways in which knowledge is made and communicated, the fact that it was not always possible to tell who had written the text meant that we could not necessarily attribute the content to the child participant.

For example, the communications in Extract 5 came all together in quick succession after a long period of silence; it seems likely they were input by a parent, although the level of collaboration may have been high. Without further investigation such examples are of dubious value. Nevertheless, it does show an interest in the project from a parental perspective, and indicates that further interviews with parents as well as children would be productive.

\section{Extract 5}

Did u know there is a new moon any day now that should bring in better weather! Elliot

Candice i have noticed that the wind gets up just before it rains. The showers are heaviy too!! Elliot

Thank you for letting me use this phone, i have taken a different view on the environment!Elliot

(2) I wanted to find out where children's information was coming from. One aim of the project was to determine which sources of information were most readily accessed by children of this age, and what sense the children made of that information. This meant having access to the original "texts". I (CS) sent the following message to try to get this kind of information:

CS: If u send some info, tell me how you know. E.g. Was it newsround, tv, paper, etc. Ok.? Candice 
The following examples include reference to "the net", "the radio", "the news", and talking to individuals - "mum" and "my cousin". While this is fascinating in terms of the range of sources of information, and also the mediation of information, the data leaves many gaps.

Extract 1
E1: This morn barak Obama said that soler and wind are the way forward
CS: Hi Don. How do you know about Barack Obama?
E1: Mum told me

For example, in Extract 1 "mum" presumably heard the news item about Barack Obama on the radio, and then relayed it to her son, perhaps because she knew he was participating in a climate change research project. Was this a normal way of communicating? Did the boy hear the radio too, but not pay attention to it until his mother alerted him to it? Would they normally talk about this topic?

\section{Extract 2}

The pope has a lot of solar panals in his cort yard!ecotalcker 3

Pope text was a news item.

How do you know that, Tom?

I know that of the news ecotalcer 3

It is not clear in Extract 2 whether the news was on TV, radio, newspaper - although, assuming "of" stands for "off", "off the news" implies TV or possibly radio. The limitation is that it is not possible to trace the text back to its source.

Extract 3
E4: Hi just been on net, read about an earthquake in caribbean it was 7.1
magnitude it killed at least 1 person .
CS: Wow. Thanks alan. Did anyone else hear about that earthquake.? If so
where? C.
E 1: Listend to radio cartarita rite islands going under water!
E4: Also read about tourism officials being mad as they lost millions cos the
weather report said it would rain but it was hottest day of th ... [message
terminated at 140 characters]

Similarly, Extract 3 refers to the "net" and the "radio". Subsequent investigation suggested the child E1 was referring to an item about the Cartaret islands on Radio $4 .{ }^{10}$ The "net" is less easy to determine. Conversations with the children concerned afterwards indicated that some accessed news items which popped up as they logged into their email accounts. Extract 3 is also dubious in that E4's contributions are likely

\footnotetext{
${ }^{10}$ http://www.bbc.co.uk/programmes/b00kj9z1
} 
to have been written by the boy's mother: an analysis of the spelling here in comparison with his school work indicates an unusual degree of accuracy. (The phones were not automatically set to use predictive text.)

Extract 4
E5: I went to london yesterday with my choir and when we got back at
broughton
E5: Sorry i didnt mean to send that anyway as we got back at broughton which
is just outside of preston if u looked over the city all u coul ... [message
terminated at 140 characters $]$
[message continued $]$ ution. From no 5
CS: Hi Ben. How did you know it was air pollution? Candice
E5: I asked my cousin what it was because the sky looked strange

Extract 4 is an example of a child accepting knowledge from a family member: the cousin is older than Ben, and is consulted in the same way a parent might be.

The first part of the extract also indicates some of the limitations of the technology: the child has erroneously sent a message; he has also encountered the problem of only being able to use 140 characters in one message (also illustrated in Extract 3). The data is therefore slightly incomplete.

\section{Preliminary findings and discussion}

Observations of classes and discussions with teachers revealed that the topic of climate change was covered inconsistently in different schools. This was largely because the topic was not a designated topic in the curriculum. At secondary school level climate change is incorporated into the curriculum in Geography, Science, and PSHE (Personal, Social, Health and Economic Education), which it is proposed should be made mandatory at both primary and secondary level. At present there are fewer prescribed opportunities for learning about climate change in primary school, and it is often dependent on teachers' interpretation of the National Curriculum, or their introduction of extra-curricular activities. Some materials are available for use at Key Stage 2 (age 7$11)^{11}$; however, without the topic being prescribed by the curriculum there is not always perceived to be the space or time in the curriculum.

The comparison of the two schools indicated that there appeared to be a significant difference in the level of knowledge and understanding between children at the eco and non-eco schools. For example, on a "test" of children's levels of carbon

\footnotetext{
${ }^{11}$ e.g. lesson plans from Project Genie (2008)

http://www.globalcoolfoundation.org/download_introduction_to_cl.pdf , or Oxfam's week of activities on Climate Chaos http://www.oxfam.org.uk/education/resources/climate_chaos/.
} 
literacy using a website game, ${ }^{12}$ eco-school children consistently scored more highly. However, the levels of interest and inquiry in the children were by no means lower at the non-eco school. For example, children who had thought that a plane would produce less carbon than a train "because it looks cleaner" were genuinely interested to find that they were mistaken, and children who claimed they knew very little about causes of climate change were keen to learn. Rather, it emerged that teachers are sometimes reluctant to broach environmental issues at school, because the questioning from children on the subject has made them insecure about their own understanding. The OECD Environment School Initiative (ENSI Project) (1995) and Rickinson (2001), both indicate that teachers and pupils operate from different perspectives on many environmental issues, and my observations appeared to confirm this. Ironically, it can be the children's explicit interest which leads to a lack of input from teachers. There is also a feeling amongst teachers that they do not wish to frighten the children; I encountered no evidence of children feeling frightened, but acknowledge that this aspect requires further investigation. Cotton (2006) and Ramsey and Hungerford (1989) address the difficulties of teaching controversial issues, while Ungar (2000) and Boyes \& Stanisstreet (1997) expose public confusion between the ozone hole and global warming. According to secondary school teachers interviewed, there is often confusion amongst Year 7 and 8 students who encounter climate change in the curriculum.

The eco-school was more likely to introduce environmental issues into the curriculum. For example, children were asked to design eco-homes as part of their approach to the "mountain environment" topic (unit 15) in Year 6, and children wrote and performed an "eco-rap" song, incorporating aspects of literacy and music. The ecoclub involved meetings which required minutes to be taken, notices to be written, and debates to be had, all undertaken by children throughout the school. It was significant that eco initiatives were often spearheaded by non-teaching staff such as caretakers and teaching assistants, often being dependent on individuals within a school, rather than a whole school policy. In the eco-school the pursuit of eco green flags (awarded by the government initiative) was largely led by one teaching assistant, while in the non-eco school the caretaker took on the notion of recycling paper with enthusiasm. It was notable that the demonstrated values of these schools were indeed reflected in the practices and comments of the children in school, but these practices did not necessarily travel outside of the school domain into other aspects of the children's lives.

Despite its limitations, the data produced by the mobile phone method offered some insights. None of the sources of information indicated in the transcripts seemed to be targeted primarily at children. This observation was supported in interviews with children, who referred to watching TV programmes such as "Grand Designs", a British programme about home-building projects, often incorporating "eco-friendly" features, which is generally scheduled for transmission at 9pm. (In the UK, the "watershed" for programmes appropriate for children is $9 \mathrm{pm}$.)

The range of topics covered by the children in response to the vague directive "anything to do with climate change" was wide, but relevant. In their tweets and photos, the children referred to the weather, the climate, nature, traffic, pollution, solar panels, recycling, etc. One boy, who actually contributed little in the way of tweets, had taken photographs of his house in a violent rainstorm, a collection of plastic bags, a cartoon joke about a lawnmower shop opening in the Arctic, and a portable radio signifying hearing the news. This indicated a relatively holistic approach to the topic of climate change - and indeed represents a broad cross-section of what might be termed "texts",

12 "The climate change game" at http://www.globallink.org.uk/exhibitions/cc/game.html 
and taken together could be seen as evidence that he and many of the other children understood some of the relationships within the carbon cycle. Whether the fact that these children attended an eco-school influenced these results is yet to be tested.

\section{"Situated" carbon literacy and associated practices}

One of the children in the standard non-eco school, Ellie, made a pertinent point in a discussion about what they learnt about climate change at school:

"We just store it in our brains, and keep it there. We know it, but it just stays in there. We don't do anything about it. We forget about it until our next science lesson." (Ellie, age 10)

Ellie appears to have articulated an example of "situated knowledge". It has been argued that literacy practices are situated (Barton, Hamilton \& Ivanic 2000), and not necessarily transferable from one domain to another. To extrapolate from Ellie's observation, we might conclude that she is not yet carbon literate, in that she has not "applied" her theoretical knowledge to life. Another example of such situated carbon literacy comes from a child's parents who described how their son complained about going to school on the bus, even though he was an active member of the eco committee at school. And another boy exclaimed, "It's not fair! They've pinched our idea!" when hearing that another school had followed the example of his own eco-school and installed a wind turbine. Clearly such expressions seem to be missing the point: so are these children some way off being "carbon literate"; or are their "carbon literacy practices" situated in school, but not crossing the boundary into home or community?

An analysis of a particular example might be illuminating here. One of the schools involved in the project had a well-established composting system. An important member of the team was Ryan, who wore a badge which designated him "compost champion". He took seriously his role which followed a routine whereby all food and garden waste was sorted and composted. Nevertheless, a discussion with his family revealed that the household he lived in did not have such a system for composting, and Ryan's activities were confined to the domain of school. This can be represented in Table 4 using the relevant components of a social practice adapted from Table 1.

Table 4: A carbon literacy practice as a social practice

We can see from this that the transfer of the practice of composting from school to home is not straightforward. The configuration of the elements of the practice of composting for Ryan is significantly different at home from at school. Nevertheless, the comment from Ryan reproduced in Table 2: "If you didn't do all the compost it'd be like like the people, if you didn't actually act on it, it would be like the world would smell of diesel and stuff because we didn't care and then eventually we'd get so hot" indicates a link between his school practices and their importance beyond the immediate confines of school. The references to "acting on it" and "because we didn't care" bring together notions of behaviour and feelings in a simplistic but revealing way. All social practices crucially involve these elements, amongst many others.

As in social practices more generally, and with reference to literacy practices in particular (see Satchwell \& Ivanic 2010; Ivanic 2006), issues of identity are crucial. In the same way that FE student Gemma identified herself more positively as a family 
member than as a student, our eco-composting champion, Ryan, found more satisfaction - and more agency - in his prestigious role at school than at home. Institutional factors such as the availability of facilities and the norms of behaviour - at school, at home, in the community - are also critical in the analysis of practices, as well as in any attempts to reconfigure - to increase or improve - them.

\section{Children as agents of change}

The examination of the permeability of borders between different domains of life leads to a second issue, namely the assumption - either implicit or explicit - within much of the literature associated with climate change and education, that children can be the agents of change (Hart 1995, 1997; Chawla 2002; Checkoway \& Gutierrez 2006; PercySmith \& Thomas 2009; Ecosan at WASTE project). ${ }^{13}$ This assumption is based in part on programmes where a model of children as agents of change has appeared to be successful, for example in helping parents to stop smoking. Project Genie, $\frac{14}{\text { an }}$ initiative designed to educate children about climate change and to change behaviours to save carbon, has as its strapline: "children taking charge on climate change". The book related to the project, The Genie in the Bottle (Montgomery 2007) states:
"Reaching 3 million children between 7 and 11 years old in the UK, and up to 29 million adults over whom they have influence, our "summed individual actions" really can make a difference in saving money, and saving our planet." (italics added.)

The author of this text is an intensive care consultant and Director of the Institute for Human Health and Performance at University College, London. He has said,

"Children can actually achieve massive change. Pester power is crucial. We know that from what we've learned in health care. Your own daughter telling you you're going to die from smoking is much more powerful than any government poster saying so" (Montgomery, quoted in Hickman 2009).

If we examine closely the cases of children's responses to lung cancer and climate change as examples of social practice, there are clear differences in the way in which children's "pester power" will be effective; for example, in terms of Feelings, Values and Identities to do with family relationships, responsibility, guilt, agency, etc.

A second example of the assumption of children as agents of change is the EcoSchools programme. In 2006 the then Department of Children, Schools and Families (DCSF) aimed for every school to be "a sustainable school" by 2020, wherein young people are prepared "for a lifetime of sustainable living, through its teaching, its fabric and its day-to-day practices ... guided by a commitment to care: for oneself; for each other (across cultures, distances and generations); and for the environment itself (far and near)." 15 The introduction of eco-schools makes the assumption that children are able to "make a difference":

\footnotetext{
${ }^{13}$ http://www.ecosan.nl/page/910 )

${ }^{14} \mathrm{http} / / / \mathrm{www}$. projectgenie.org.uk/

${ }^{15}$ http://www.teachernet.gov.uk/sustainableschools
} 
"Climate Change is the greatest environmental challenge facing the world today... I believe that schools have a special role to play in helping pupils understand the causes and impact of our changing environment and showing the ways in which they can make a real difference." (David Miliband).

This sounds convincing, but it is based on a model of behaviour change being brought about through a straightforward model - which has been considered an effective strategy in health care (stopping parents smoking) and in marketing (persuading parents to buy certain products), but is not necessarily transferable to other contexts. It is, of course, laudable for schools to demonstrate practices which conserve carbon: every school committed to reducing its carbon footprint is making a valuable contribution. The question is whether the practices transfer from that school into the lives of the children who attend it. The consequences of an approach which assumes this transfer are described by Shove (2010) in her account of the ABC model:

"I suggest that framing the problem of climate change as a problem of human behaviour marginalises and in many ways excludes serious engagement with other possible analyses including those grounded in social theories of practice and transition. This prompts further discussion of the relationship between theories of change and modes of governance, resulting in the proposition that policy - as currently configured - is incapable of moving beyond the $\mathrm{ABC}$ - this being an account of social change in which "A" stands for attitude, "B" for behaviour and " $\mathrm{C}$ " for choice. The popularity of the $\mathrm{ABC}$ framework is an indication of the extent to which responsibility for responding to climate change is thought to lie with individuals whose behavioural choices will make the difference." (p.1274)

Data from the eco-school in the project also made an assumption of transfer being possible from one domain to another. For example, the comment "I am helping the environment in the school and at my house and out of school and in town" (Charlotte, age 10, written communication) is a claim that there are no boundaries to be overcome. A poster displayed in the school hall entitled "Top tips for your eco packed lunches" listed several commands, for example,

"Ask your parents to buy food that is grown or made as near to [your home town] as possible. If your food has had to be transported a long way it is a waste of fuel and adds to global warming."

While the school has assumed the transferability of knowledge and practices, children's asking their parents to change their practices is not equivalent to parents changing their practices. Any number of aspects of that practice require consideration, including economic and mobility issues, values and attitudes, family hierarchies, and so on. In addition, educational programmes about climate change assume that making sense of climate change is the crucial first step to changing behaviour, and embody the notion that responses to climate change are dependent on knowledge. However, there is evidence to suggest that education is not always an effective motivating force for action (e.g. Chawla 1999; Rose et al, 2007). This is for several reasons, including recognising the enormity of the problem, and seeing any individual action therefore as disproportionate and ineffectual. Further, it is clear from work in literacy studies and education (Barton et al 2000; Ivanic et al 2009; Gee 2003; Reinking et al 1998; TuomiGrohn and Engestrom 2003) that the transfer of linguistic and semiotic signs is by no means equivalent to the transfer of knowledge, values or functions. In other words, a 
school lesson or a computer game about climate change and its effects does not automatically mean that a child will turn the lights off at home. Nor does a policy of recycling lunch box waste at school transfer directly to carrying out similar practices in the community. Questions remain: To what extent, then, does education about climate change make a difference to children's practices, and those of their households and communities? What might the differences be for children attending an eco school? Are the literacy practices associated with climate change different, quantitatively or qualitatively, in different kinds of schools?

\section{Children's carbon literacy literacy practices}

Whether or not education makes a difference to carbon literacy practices, children are constantly making sense of the world around them, based on what information they have and how they interpret it. Making sense of climate change involves a whole range of social practices, including discussions and media consumption, in households, among communities, and in schools. Many are "literacy practices", meaning that they involve engaging with paper or electronic texts - leaflets, pamphlets, advertisements, articles in newspapers, magazines, journals, text books, novels, websites - as well as films and TV programmes. Such texts embody a complex range of purposes and audiences, and incorporate a variety of discourses about climate change (IPPR 2006, 2007). The aim here is to examine the social practices engaged in by children during and as a result of coming into contact with texts about climate change. These might be defined more accurately as "carbon literacy literacy practices". This notion can be exemplified with reference to some of the texts encountered by children, which form part of literacy events encountered during the project (Fig 2).

Figure 2. Carbon literacy literacy events in different domains of children's lives

A literacy event is an observable instantiation of a literacy practice. Figure 2 shows examples of literacy events relating to climate change found occurring during the project in the three domains of children's lives - home, school and community. It also shows events which can be seen to cross or fall between domains. For example, an event observed in school was a visit from an outside organisation about reducing energy, during which children were given information, and asked to complete various tasks to show their understanding of the carbon cycle. At the end of the session each child was asked to write on a post-it note what they would do differently at home as a result of the day. This was a clear attempt to bring about change in people's behaviour at school, at home and in the community, through the influence of children. Its longterm success however, is likely to be limited, because this event was not an instantiation of a practice. Without being part of a social practice, i.e. engaged in regularly by group(s) of people with norms, values and various kinds of infrastructure in place, it is unlikely to be sustainable.

On the other hand, a social practice engaged in regularly by one boy's family was visiting the council tip on a Sunday to recycle large items. Related data collected included a series of photographs of one such trip taken on his mobile phone (see below), along with Twitter feeds, followed up by a face-to-face conversation. This was an established routine, and although the aims may have been different for different participants - e.g. to make more space at home, to save the environment, to have a family outing - the resources, the will, and the infrastructure were all in place to enable it to happen on a regular basis. 
Figure 3. Photographs taken by a boy on a visit to the council tip

I was also told about a visit from the local council recycling team which involved taking their recycling wagon to the school playground and allowing children to 'drive' the truck. This was a highly memorable occasion, and news travelled from the school to the home. This might indicate a successful communication of knowledge across all three domains therefore, particularly as it coincided with the council's distribution of recycling boxes to homes and detailed instructions on how, when and where to use them. Although the focal point of the children's memory of the event was riding in the truck, rather than applying the recycling advice in the leaflet they were given afterwards, this can be see as a potentially successful transfer of a social practice across domains.

Work by Marsh (2003) and Pahl and Rowsell (2005) has focused on bringing texts from the domain of home into that of school, creating a "third space" where children's "funds of knowledge" (Moll 1992) can be drawn upon to increase opportunities for learning. Starting from a similar principle, the Literacies for Learning in Further Education project (Ivanic et al 2009) made it clear that literacies are not simply transferable from one context to another, but are crucially context-bound. Therefore it was not a solution to import a literacy practice from one domain into another; rather a careful analysis of literacy practices enabled tutors to harness aspects of practices which students engaged with readily, and to introduce them into the practices required for college courses. Applying this notion to carbon literacy practices might suggest that the visit from the council was certainly on the right lines, combining something which the children engaged with wholeheartedly with a message about the environment, in conjunction with the provision of resources within the community. Building on this idea to make the letter about eco packed lunches more effective, the letter could be co-constructed by the children themselves, and perhaps include practical incentives such as the school providing locally-sourced lunch ingredients to make the practice one which could be engaged in more readily by many families, and to increase its sustainability.

The challenge - and it is an extreme challenge - is to understand the relationship between interaction with environmental texts, and associated behaviour. Many studies have investigated this link; for example, Keizer et al (2008), in line with the psychological "broken windows theory" which suggests that people replicate the behaviour manifested in their environment, found that signs prohibiting leaving litter can have the opposite effect. However, the long-term and cumulative effects are much more difficult to determine. Also, there is much less work on the relationships between different domains of life. My argument here is that the consideration of "carbon literacy" be seen as consideration of social practices relating to the environment.

This paper has touched on several important issues - theoretical, methodological, and practical. It has presented a view of carbon literacy practices with reference to theory in literacy studies. In order to go beyond the ABC model, carbon literacy practices need to be seen - and to be researched - in a way which acknowledges their potential situatedness, the complexity of their configuration, and the difficulties of transition between different areas of life. In order to understand how far education about climate change has an impact on children's practices, we need to examine the multimodal forms in which that education is manifested, the ways in which it is interpreted, and the ways in which it is incorporated - or not - into everyday life. 
(8206 words)

\section{References}

Barton, D. (2007) Literacy: An Introduction to the Ecology of Written Language $\left(2^{\text {nd }}\right.$ edn), Oxford: Blackwell.

Barton, D., Hamilton, M., Ivanic, R. (2000) Situated Literacies, London: Routledge.

Baynham, M. (1995) Literacy Practices: Investigating Literacy in Social Contexts, London: Longman.

Blake, J. (1999) Overcoming the 'value-action gap' in environmental policy: Tensions between national policy and local experience, Local Environment, Vol. 4, no. 3, pp. 257-278.

Boyes, E. and Stanisstreet, M. (1997) 'Children's models of understanding of two major global environmental issues (ozone layer and greenhouse effect)', Research in Science and Technological Education, 15, 1, 19-29.

Chawla, L. (1999) "Life paths into effective environmental action", Journal of Environmental Education; Fall 1999, Vol. 31 Issue 1, p15-27.

Chawla, L. (2002) Growing up in an urbanizing world, London: Earthscan.

Checkoway, B. \& Gutierrez, L. (eds) (2006) Youth participation and community change, Binghamton, NY: Haworth Press.

Corbett, J. (2006) Communicating Nature: how we create and understand environmental messages, Washington DC: Island Books.

Cotton, Deborah R. E. 'Teaching controversial environmental issues: neutrality and balance in the reality of the classroom', Educational Research, 48, 2, 223-241.

Gayford, C. (2009) Learning for sustainability: from the pupils' perspective, World Wildlife Fund.

Gee, J. (2003) What video games have to teach us about literacy and learning, Hampshire: Palgrave Macmillan.

Gutierrez, K., Rymes, B. and Larson, J. (1995) Script, counterscript, and underlife in the classroom: James Brown versus Brown v. Board of Education. Harvard Educational Review 65(3): 445-471.

Hall, N., Robinson, A. and Crawford (2000) "Young children's exporations of letterwriting", in Barton, D. and Hall, N. (eds) Letter Writing as Social Practice, London: John Benjamins Publishing.

Hart, R. (1995) Affection for nature and the promotion of earth stewardship in Childhood, NAMTA Journal, vol. 20, no. 2, 58-68.

Hart, R. (1997) Children's Participation: The theory and practice of involving young citizens in community development and environmental care, London: Earthscan.

Heath, S.B. (1983) Ways with Words: Language, life, and work in communities and classrooms. Cambridge: Cambridge University Press.

Hickman, L. (2009) http://www.guardian.co.uk/environment/2009/may/22/climatechange-children-education-books

Hull, G. \& Schultz, K. (2001) Literacy and learning out of school: A review of theory and research. Review of Educational Research, 71(4), 575-611.

Hull, G. and Schultz, K. (eds) (2002) School's Out! Bridging Out-of-School Literacies with Classroom Practice. New York: Teachers College Press, 2002.

IPPR/Linguistic Landscapes (2006) Warm Words: How are we telling the climate story and can we tell it better? (available to download at www.ippr.org)

IPPR (2007) Warm Words II: How the climate story is evolving and the lessons we can learn for encouraging public action, Energy Saving Trust and ippr. 
Ivanič, R., Barton, D., Satchwell, C., Edwards, R., Fowler, Z., Mannion, G., Miller, K., Smith, J., Martin-Jones, M., Hughes, B. (2009) Improving Learning in College, London: Taylor \& Francis.

Ivanič, R. and Pardoe, S. (2009) Literacies for Learning in FE, DVD.

Ivanič, R. and Satchwell, C. (2007) "Boundary crossings: Networking and transforming literacies in research processes and college courses", Journal of Applied Linguistics, Vol. 4, No. 7.

Ivanic, R. (2006) "Language, learning and identification". In R. Kiely, P. Rea-Dickens, H. Woodfield and G. Clibbon (eds) Language, Culture and Identity in Applied Linguistics. Equinox.

Keizer, K., Lindenberg, S. and Steg, L. (2008) The spreading of disorder, Science, Vol. 322 no. 5908 pp. 1681-1685.

Kenner, C. (2000) Home Pages: Literacy Links for Bilingual Children, Stoke on Trent: Trentham Books Ltd.

Kerkham, L. \& Comber, B. (2007) Literacy, Places and Identity: The complexity of teaching environmental communications, in Australian Journal of Language and Literacy, 30, 2, pp.134-148.

Mannion, G. and Ivanic, R. (2007) "Mapping literacy practices: theory, methodology, methods", International Journal of Qualitative Studies in Education Volume 20, Number 1, January 2007 , pp. 15-30(16).

Mannion, G., Miller, K., Gibb, I,. \& Goodman, R. (2009) Reading Writing and Resonating: striking chords across the contexts of students' everyday and college lives. Pedagogy, Culture, Society, Vol. 17(3), pp 323-339.

Marsh, J. (2009) One-Way Traffic? Connections between Literacy Practices at Home and in the Nursery, British Educational Research Journal Vol. 29, No. 3 (Jun., 2003), pp. 369-382.

Moll, L. (1992) Funds of knowledge for teaching: using a qualitative approach to connect homes and classrooms, Theory into Practice, Vol. XXXI, Number 2.

Montgomery, H. (2007) The Genie in the Bottle, available from http://www.projectgenie.org.uk/Teachers.aspx.

Pahl, K. and Rowsell, J. (2005) Literacy and Education: Understanding the new literacy studies in the classroom, Sage Publications Ltd.

Percy-Smith, B. and Thomas, N. (eds) (2009) Handbook of children's participation: Perspectives form theory and practice, London: Routledge.

Pooley, Colin G. and Whyatt, J. Duncan and Walker, Marion and Davies, Gemma and Coulton, Paul and Bamford, Will (2010) Understanding the school journey : integrating data on travel and environment. Environment and Planning A, 42 (4). pp. 948-965.

Project Genie (2008) http://www.globalcoolfoundation.org/download_introduction_to_cl.pdf

Ramsey, J. and Hungerford, H. (1989) 'So ... You want to teach issues?' available: http://coekate.murraystate.edu/courses/edu515/Readings/PDF/TeachingIssues.pd f

Reinking, D. et al (eds) (1998) Handbook of Literacy and Technology: Transformations in a post-typographic world, NJ: Lawrence Erlbaum Assoc.

Rickinson, M. (2001) Learners and Learning in Environmental Education: A critical review of the evidence, Environmental Education Research, Volume 7, Issue 3, 2001, 207-320. 
Rose, C., Dade, P. and Scott, J. (2007) Research Into Motivating Prospectors, Settlers and Pioneers To Change Behaviours That Affect Climate Emissions, UK: Campaign Strategy.

Satchwell, C. (2006) 'Literacy around the clock: an examination of the clock activity', Proceedings of $3^{\text {rd }}$ International Conference - What a Difference a Pedagogy Makes: Researching Lifelong earnig \& Teaching conference (2005), Centre for Research in Lifelong Learning.

Satchwell, C. and Ivanic, R. (2009) "Textual mediation of learning in Further Education”, in M.S. Thorpe, G. Biesta and R.G. Edwards (eds) Rethinking Contexts for Learning and Teaching, London: Routledge.

Satchwell, C. and Ivanic, R. (2010) "Reading and writing the self as a college student: Fluidity and ambivalence across contexts", in K. Ecclestone, G. Biesta and M. Hughes (eds.) Lost in transition? Change and becoming through the lifecourse, London: Routledge Falmer.

Shove, E. (2010) Beyond the ABC: climate change policy and theories of social change, Environment and Planning A, vol 42, pp 12873-1285.

Street, B. (1984) Literacy in Theory and Practice, Cambridge: Cambridge University Press.

Tuomi-Gröhn, T. \& Y. Engeström (eds.) (2003) Between school and work: New perspectives on transfer and boundary crossing. Amsterdam: Pergamon.

Ungar, S. (2000) "Knowledge, ignorance and the popular culture: climate change versus the ozone hole", Public Understanding of Science, July 2000 9: 297-312. 
Table 1. Aspects of a literacy practice

\begin{tabular}{|l|l|}
\hline Participants and relationships & Activity/processes \\
\hline Audience(s) & Content/topic(s) \\
\hline Purpose(s) & Text type(s)/genre(s) \\
\hline Media & Place/time \\
\hline Modes & Values \\
\hline Artefacts: tools and resources & Identities \\
\hline
\end{tabular}


Table 2. Children's responses in climate change discussion

\begin{tabular}{|c|}
\hline $\begin{array}{l}\text { "Vehicles and fumes - and the world gets hotter, and that's climate change." } \\
\text { (Jenny age 10) }\end{array}$ \\
\hline $\begin{array}{l}\text { "Greenhouse gases are bad by heating up and burning things, that makes the sun } \\
\text { get bigger and then animals die and then eventually the things you need die out } \\
\text { and then the world will blow up." (Daniel, age 11) }\end{array}$ \\
\hline $\begin{array}{l}\text { "It's where the ice melts and the water goes into the sea and the sea goes into the } \\
\text { land and could drown everyone." (Fred age 11) }\end{array}$ \\
\hline $\begin{array}{l}\text { "If you didn't do all the compost it'd be like like the people, if you didn't } \\
\text { actually act on it, it would be like the world would smell of diesel and stuff } \\
\text { because we didn't care and then eventually we'd get so hot." (Ryan age 10) }\end{array}$ \\
\hline
\end{tabular}


Table 3. Children's written responses to letters

My mum and dad were really interested about me talking to you. She sat me down and we had arak about what, know. My mum asked if I was going to do any thing like recycoling is aid yes:

I honestly did int think I knew so much about the enviroment and ever since I've been talking to you I have been walking home from school alt more than often and thanks to you I have been really thinking about and have started to recycle even so I have really enjoyed talking to you candice and

I really enjoyed playing the game as 1 found out new things about how to save the environment in the house. I remember when you asked us what we knew at the beginning; we hardly knew anything at the end we had learnt aloft more. 
Table 4. A carbon literacy practice as a social practice

\begin{tabular}{|l|l|l|l|l|l|}
\hline & $\begin{array}{l}\text { Ryan } \\
\text { composting } \\
\text { at school }\end{array}$ & $\begin{array}{l}\text { Ryan } \\
\text { composting } \\
\text { at home }\end{array}$ & $\begin{array}{l}\text { Ryan } \\
\text { composting } \\
\text { at school }\end{array}$ & $\begin{array}{l}\text { Ryan } \\
\text { composting } \\
\text { at home }\end{array}$ \\
\hline $\begin{array}{l}\text { Participants } \\
\text { and } \\
\text { relationships }\end{array}$ & $\begin{array}{l}\text { Ryan with } \\
\text { peers and } \\
\text { teachers }\end{array}$ & $\begin{array}{l}\text { Family } \\
\text { members }\end{array}$ & $\begin{array}{l}\text { Activity/ } \\
\text { processes }\end{array}$ & $\begin{array}{l}\text { Clearly } \\
\text { defined } \\
\text { routine }\end{array}$ & Undefined \\
\hline Audience(s) & $\begin{array}{l}\text { School peers } \\
\text { and teachers }\end{array}$ & $\begin{array}{l}\text { Family } \\
\text { members }\end{array}$ & Content/topic(s) & $\begin{array}{l}\text { Composting } \\
\text { waste }\end{array}$ & $\begin{array}{l}\text { Composting } \\
\text { waste }\end{array}$ \\
\hline Purpose(s) & $\begin{array}{l}\text { Fulfilling } \\
\text { eco role }\end{array}$ & Unclear & Place & School & Home \\
\hline $\begin{array}{l}\text { Artefacts: } \\
\text { tools }\end{array}$ & $\begin{array}{l}\text { Designated } \\
\text { composting } \\
\text { and } \\
\text { ans, rubber } \\
\text { resources }\end{array}$ & Unavailable etc. & Time & $\begin{array}{l}\text { Specified } \\
\text { times }\end{array}$ & $\begin{array}{l}\text { Unspecified } \\
\text { times }\end{array}$ \\
\hline Identities & $\begin{array}{l}\text { Composting } \\
\text { champion }\end{array}$ & $\begin{array}{l}\text { Family } \\
\text { member }\end{array}$ & Values & $\begin{array}{l}\text { In line with } \\
\text { school eco } \\
\text { status }\end{array}$ & Unclear \\
\hline
\end{tabular}

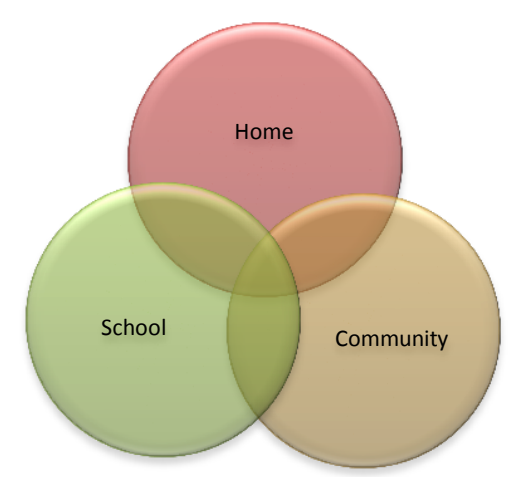

Figure 1. Domains for children's carbon literacy practices 


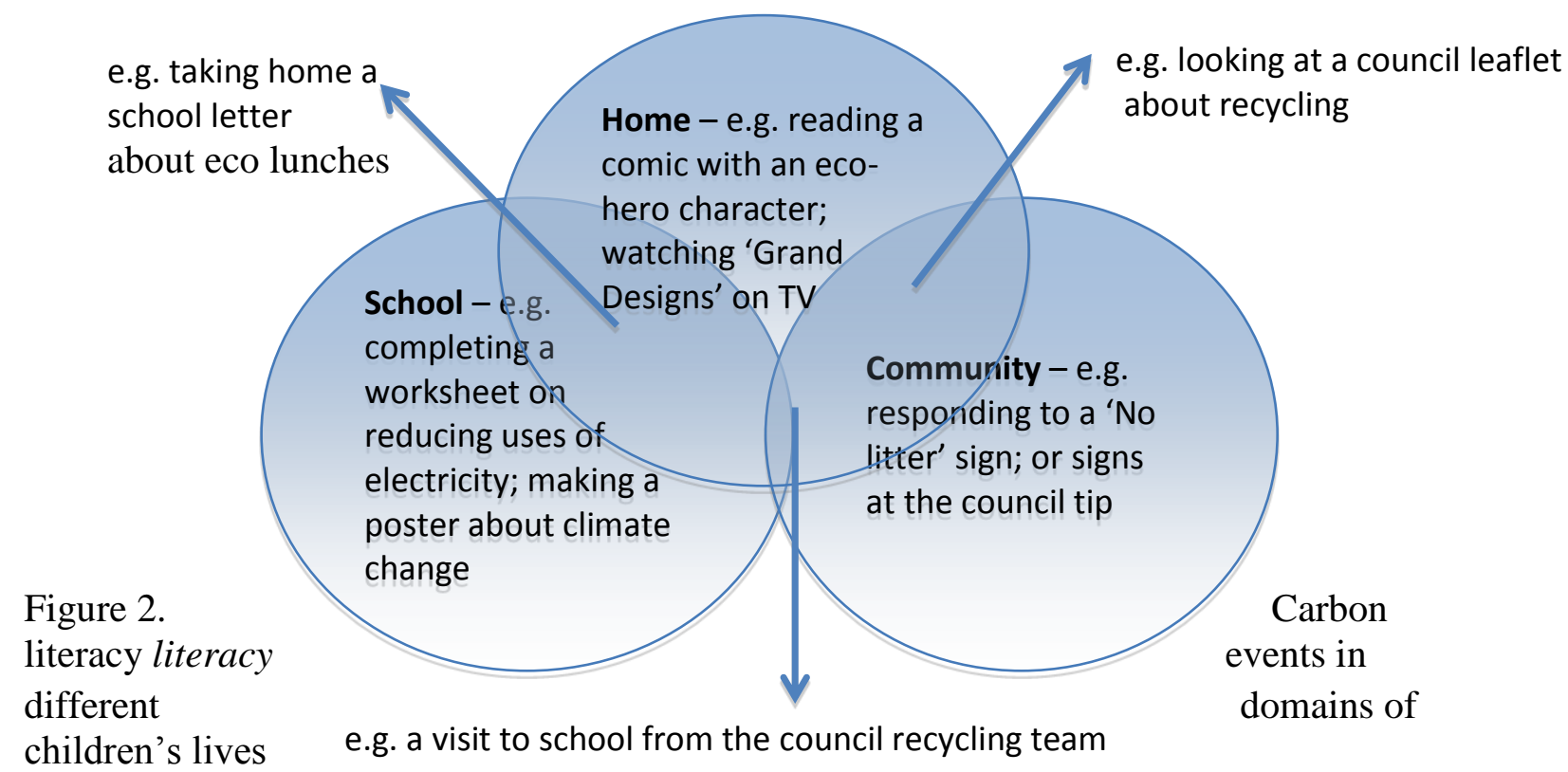



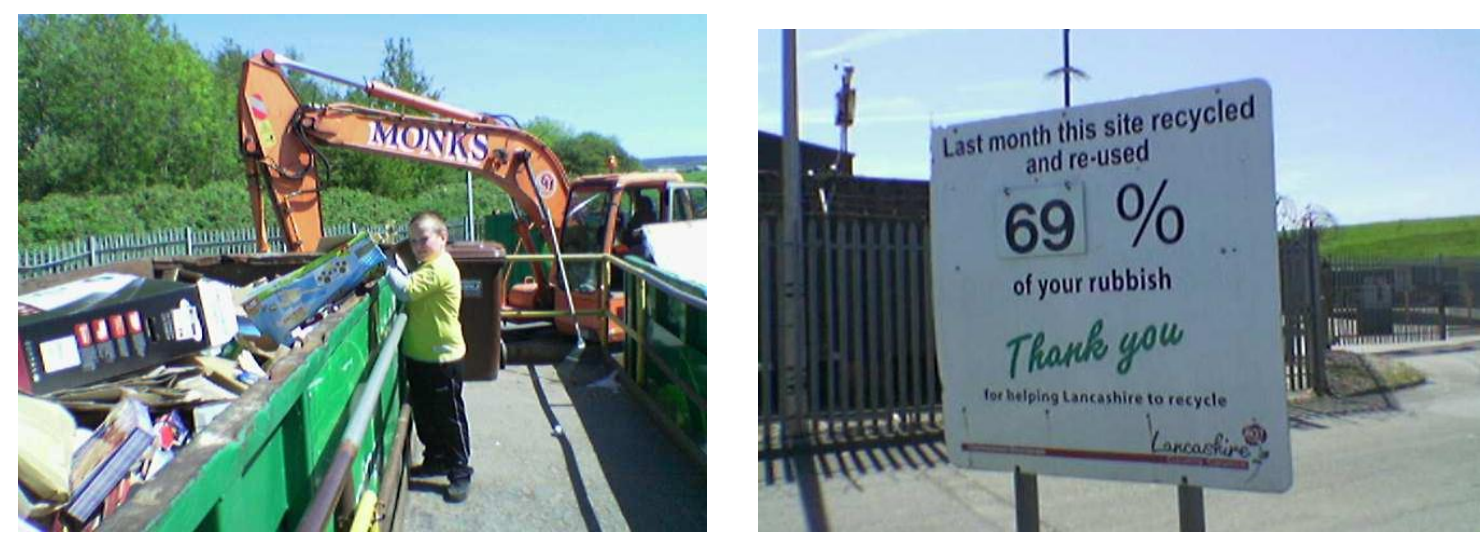

Figure 3. Photographs taken by a boy on a visit to the council tip. 
Figure 1. Domains for children's carbon literacy practices.

Figure 2. Carbon literacy literacy events in different domains of children's lives.

Figure 3. Photographs taken by a boy on a visit to the council tip. 